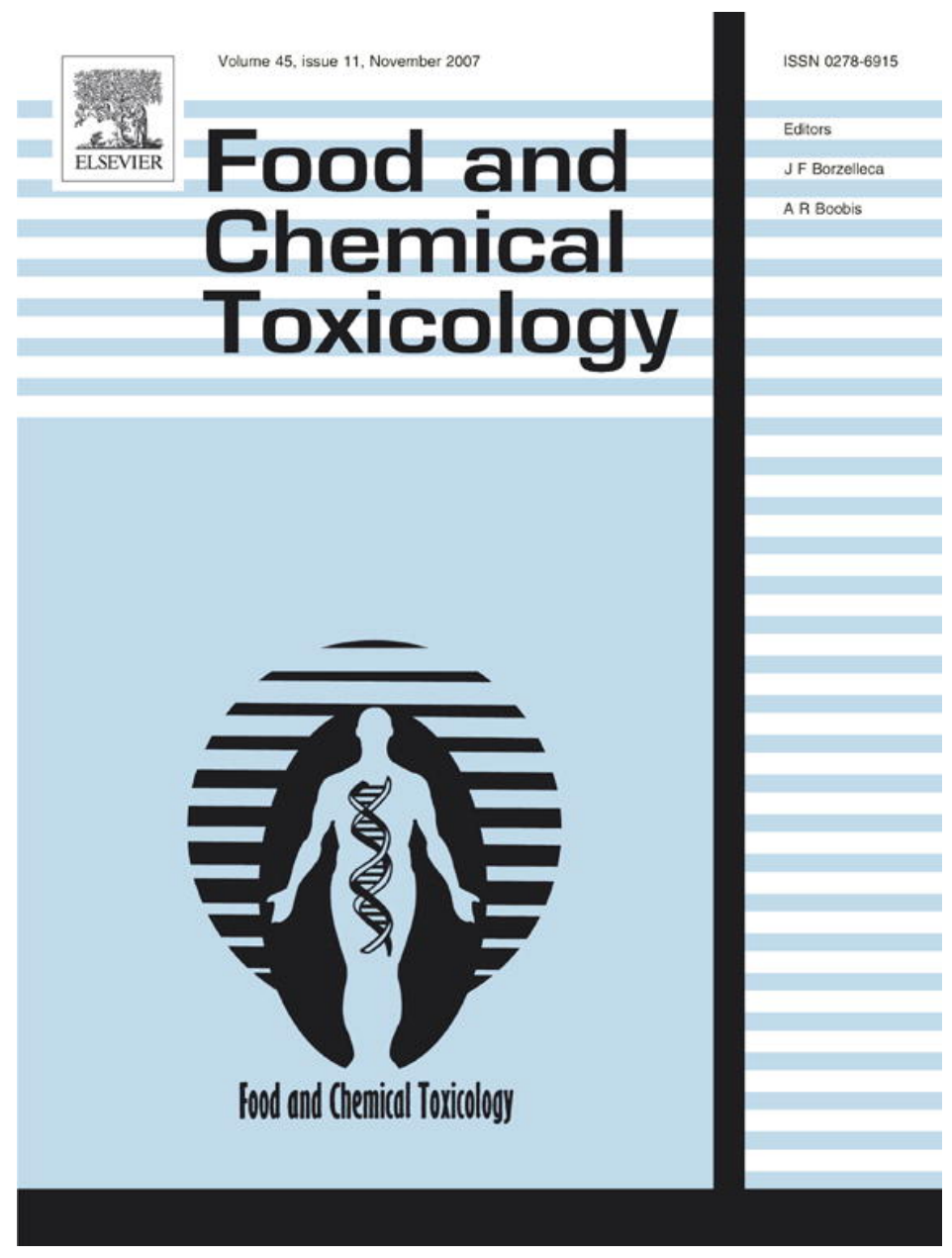

This article was published in an Elsevier journal. The attached copy

is furnished to the author for non-commercial research and education use, including for instruction at the author's institution, sharing with colleagues and providing to institution administration.

Other uses, including reproduction and distribution, or selling or licensing copies, or posting to personal, institutional or third party websites are prohibited.

In most cases authors are permitted to post their version of the article (e.g. in Word or Tex form) to their personal website or institutional repository. Authors requiring further information regarding Elsevier's archiving and manuscript policies are encouraged to visit: 


\title{
Walnut (Juglans regia L.) leaves: Phenolic compounds, antibacterial activity and antioxidant potential of different cultivars
}

\author{
José Alberto Pereira ${ }^{\mathrm{a}, *}$, Ivo Oliveira ${ }^{\mathrm{a}}$, Anabela Sousa ${ }^{\mathrm{a}}$, Patrícia Valentão ${ }^{\mathrm{b}}$, \\ Paula B. Andrade ${ }^{b}$, Isabel C.F.R. Ferreira ${ }^{a}$, Federico Ferreres ${ }^{c}$, Albino Bento ${ }^{a}$, \\ Rosa Seabra ${ }^{\mathrm{b}}$, Letícia Estevinho ${ }^{\mathrm{a}}$ \\ a CIMO/Escola Superior Agrária, Instituto Politécnico de Bragança, Campus Sta Apolónia, Apt. 1172, 5301-855 Bragança, Portugal \\ b REQUIMTE/Serviço de Farmacognosia, Faculdade de Farmácia da Universidade do Porto, Rua Aníbal Cunha, 164, 4099-030 Porto, Portugal \\ ${ }^{\mathrm{c}}$ Research Group on Quality, Safety and Bioactivity of Plant Foods, Department of Food Science and Technology, CEBAS (CSIC), P.O. Box 164, \\ 30100 Campus Univ. Espinardo, Murcia, Spain
}

Received 17 March 2007; accepted 4 June 2007

\begin{abstract}
Different cultivars of walnut (Juglans regia L.) leaves ( $C v$. Lara, Franquette, Mayette, Marbot, Mellanaise and Parisienne) grown in Portugal, were investigated in what concerns phenolic compounds and antimicrobial and antioxidant properties. Phenolics analysis was performed by reversed-phase HPLC/DAD and 10 compounds were identified and quantified: 3- and 5-caffeoylquinic acids, 3- and 4- $p$ coumaroylquinic acids, $p$-coumaric acid, quercetin 3-galactoside, quercetin 3-pentoside derivative, quercetin 3-arabinoside, quercetin 3-xyloside and quercetin 3-rhamnoside. The antimicrobial capacity was screened against Gram positive (Bacillus cereus, B. subtilis, Staphylococcus aureus) and Gram negative bacteria (Pseudomonas aeruginosa, Escherichia coli, Klebsiella pneumoniae) and fungi (Candida albicans, Cryptococcus neoformans). Walnut leaves selectively inhibited the growth of Gram positive bacteria, being B. cereus the most susceptible one (MIC $0.1 \mathrm{mg} / \mathrm{mL}$ ). Gram negative bacteria and fungi were resistant to the extracts at $100 \mathrm{mg} / \mathrm{mL}$. Lara walnut leaves were also submitted to antibacterial assays using 18 clinical isolates of Staphylococcus sp. Antioxidant activity was accessed by the reducing power assay, the scavenging effect on DPPH (2,2-diphenyl-1-picrylhydrazyl) radicals and $\beta$-carotene linoleate model system. In a general way, all of the studied walnut leaves cultivars presented high antioxidant activity $\left(\mathrm{EC}_{50}\right.$ values lower than $\left.1 \mathrm{mg} / \mathrm{mL}\right)$, being $C v$. Lara the most effective one.

(c) 2007 Elsevier Ltd. All rights reserved.
\end{abstract}

Keywords: Walnut leaves; Phenolics; Antimicrobial activity; Antioxidant properties

\section{Introduction}

The Juglans genus (family Juglandaceae) comprises several species and is widely distributed throughout the world. The Persian or common walnut (Juglans regia L.) is its best-known member, constituting an important species of deciduous trees found primarily in the temperate

\footnotetext{
${ }^{*}$ Corresponding author. Tel.: +351 273 303277; fax: +351 273325405 . E-mail address: jpereira@ipb.pt (J.A. Pereira).
}

areas and commercially cultivated in the United States, western South America, Asia, and central and southern Europe. In Portugal, this species is common in all over the country (Anonimous, 1999). Green walnuts, shells, kernels and seeds, bark and leaves have been used in the pharmaceutical and cosmetic industries (Stampar et al., 2006). Leaves are easily available and in abundant amounts, while tree bark is scarce and its collection compromise the plant life.

Walnut leaves are considered a source of healthcare compounds, and have been intensively used in traditional 
medicine for treatment of venous insufficiency and haemorrhoidal symptomatology, and for its antidiarrheic, antihelmintic, depurative and astringent properties (Van Hellemont, 1986; Bruneton, 1993; Wichtl and Anton, 1999). Keratolytic, antifungal, hypoglycaemic, hypotensive, anti-scrofulous and sedative activities have also been described (Valnet, 1992; Gîrzu et al., 1998). In Portugal, as in some other European countries, especially in rural areas, dry walnut leaves are frequently used as an infusion.

Phytochemicals, such as phenolic compounds, are considered beneficial for human health, decreasing the risk of degenerative diseases by reduction of oxidative stress and inhibition of macromolecular oxidation (Silva et al., 2004; Pulido et al., 2000; Tseng et al., 1997). They have been shown to possess free radical-scavenging and metalchelating activity in addition to their reported anticarcinogenic properties (Middleton, 1998).

In walnut leaves, naphtoquinones and flavonoids are considered as major phenolic compounds (Wichtl and Anton, 1999). Juglone (5-hydroxy-1,4-naphthoquinone) is known as being the characteristic compound of Juglans spp. and is reported to occur in fresh walnut leaves (Bruneton, 1993; Wichtl and Anton, 1999; Gîrzu et al., 1998; Solar et al., 2006). Nevertheless, because of polymerization phenomena, juglone only occurs in dry leaves at vestigial amounts (Wichtl and Anton, 1999). Several hydroxycinnamic acids (3-caffeoylquinic, 3-p-coumaroylquinic and 4- $p$-coumaroylquinic acids) and flavonoids (quercetin 3-galactoside, quercetin 3-arabinoside, quercetin 3-xyloside, quercetin 3-rhamnoside and two other partially identified quercetin 3-pentoside and kaempferol 3-pentoside derivatives) of different walnut cultivars collected at different times were studied by our group in a previous work (Amaral et al., 2004). In addition, the existence of 5-caffeoylquinic acid was also reported (Wichtl and Anton, 1999).

Some studies have demonstrated the antimicrobial activity of walnut products, particularly of bark (Alkhawajah, 1997), and the specific compound juglone (Clark et al., 1990), but information about the leaf is almost inexistent (Qa'dan et al., 2005). On the other hand, antioxidant potential of walnut leaves was not studied.

The aim of the present work was to determine the phenolic compounds and to evaluate the antimicrobial and antioxidant capacity of different cultivars of walnut leaves (Cv. Lara, Franquette, Mayette, Marbot, Mellanaise and Parisienne) grown in Portugal. For this purpose phenolics were determined by reversed-phase HPLC/DAD. The antimicrobial activity was screened using different microorganisms, namely Gram positive (Bacillus cereus, B. subtilis, Staphylococcus aureus) and Gram negative (Pseudomonas aeruginosa, Escherichia coli, Klebsiella penumoniae) bacteria and fungi (Candida albicans, Cryptococcus neoformans) and also 18 Staphylococcus sp. strains provided by clinical isolates. The evaluation of the antioxidant properties involved several assays: reducing power, scavenging effects on DPPH radicals and $\beta$-carotene linoleate model system.

\section{Experimental}

\subsection{Walnut leaf sample}

Walnut leaves were obtained form six Juglans regia L. cultivars: Franquette, Marbot, Mayette, Mellanaise, Lara and Parisienne, and were collected at 31st May 2006 in Bragança, northeast of Portugal $\left(6^{\circ} 46^{\prime} \mathrm{W}\right.$, $41^{\circ} 49^{\prime} \mathrm{N}, 670 \mathrm{~m}$ a.s.1.). The orchard has a planting density of $7 \times 7 \mathrm{~m}$. The trees have 22 years old, being pruned when necessary. No phytosanitary treatments were applied. The leaves were collected from the middle third of branches exposed to sunlight, put in plastic bags and immediately frozen at $-20^{\circ}$. The plant material was then freeze dried.

\subsection{Identification and quantification of phenolic compounds}

Extract preparation. For each cultivar, three powdered subsamples ( $\sim 5 \mathrm{~g} ; 20 \mathrm{mesh}$ ) were extracted with $250 \mathrm{~mL}$ of boiling water for $45 \mathrm{~min}$ and filtered through Whatman no. 4 paper. The aqueous extract was frozen, lyophilized and redissolved in water at concentrations of $100 \mathrm{mg} /$ $\mathrm{mL}$ and $10 \mathrm{mg} / \mathrm{mL}$ for antimicrobial and antioxidant activities assays, respectively.

Phenolic compounds analysis. Standards. The standards used were from Sigma (St. Louis, MO, USA) or Extrasynthèse (Genay, France). Methanol and formic acid were obtained from Merck (Darmstadt, Germany). The water was treated in a Milli-Q water purification system (Millipore, Bedford, MA, USA) before use.

HPLC-DAD system for analysis of phenolic compounds. Chromatographic separation was achieved as previously reported (Amaral et al., 2004) with an analytical HPLC unit (Gilson), using a reversed-phase Spherisorb ODS2 (250_4.6 mm, $5 \mathrm{~lm}$ particle size, Merck, Darmstadt, Germany) column. The solvent system used was a gradient of water/formic acid (19:1) (A) and methanol (B), starting with 5\% methanol and installing a gradient to obtain $15 \% \mathrm{~B}$ at $3 \mathrm{~min}, 20 \% \mathrm{~B}$ at $5 \mathrm{~min}, 25 \% \mathrm{~B}$ at $12 \mathrm{~min}, 30 \% \mathrm{~B}$ at $15 \mathrm{~min}, 40 \% \mathrm{~B}$ at $20 \mathrm{~min}, 45 \% \mathrm{~B}$ at $30 \mathrm{~min}, 50 \% \mathrm{~B}$ at $40 \mathrm{~min}, 70 \% \mathrm{~B} 45 \mathrm{~min}$ and $0 \% \mathrm{~B}$ at $46 \mathrm{~min}$. The flow rate was $1 \mathrm{~mL} \mathrm{~min}^{-1}$, and the injection volume was $20 \mu \mathrm{L}$. Detection was accomplished with a diode array detector (DAD) (Gilson), and chromatograms were recorded at 320 and $350 \mathrm{~nm}$. Spectral data from all peaks were accumulated in the $200-400 \mathrm{~nm}$ range. Data were processed on an Unipoint system software (Gilson Medical Electronics, Villiers le Bel, France).

Phenolic compounds quantification was achieved by the absorbance recorded in the chromatograms relative to external standards, with detection at $320 \mathrm{~nm}$ for phenolic acids and at $350 \mathrm{~nm}$ for flavonoids. 3-Caffeoylquinic acid was quantified as 5-caffeoylquinic acid, 3- and 4- $p$ coumaroylquinic acids were quantified as $p$-coumaric acid; the quercetin 3pentoside derivative and quercetin 3-xyloside were quantified as quercetin 3-galactoside. The other compounds were quantified as themselves.

\subsection{Antimicrobial activity}

Reagents. Ampicillin and cycloheximide were of the highest available quality, and purchased from Merck (Darmstadt, Germany). Water was treated in a Mili-Q water purification system (TGI Pure Water Systems, USA).

Microorganisms and culture conditions. CECT microorganisms were obtained from the Spanish type culture collection of Valencia University. ESA microorganisms were isolated in the Northeast Hospital Centre (Bragança-Portugal) from different biological fluids, and deposited in Microbiology Laboratory of Escola Superior Agrária de Bragança. Gram + (B. cereus CECT 148, B. subtilis CECT 498 and $S$. aureus ESA 7 isolated from pus) and Gram- (E. coli CECT 101, P. aeruginosa CECT 108 and $K$. pneumoniae ESA 8 isolated from urine) bacteria, and fungi ( $C$. albicans CECT 1394 and C. neoformans ESA 3 isolated from vaginal fluid) were used to screen antimicrobial activity of the six walnut leaves cultivars. Also 18 Staphylococcus sp. strains clinically isolated from different biological fluids were used to additionally evaluate the antibacterial activity of Lara cultivar. Microorganisms were cultured aerobically at 
$37^{\circ} \mathrm{C}$ (Scientific 222 oven model, 2003) in nutrient agar medium for bacteria, and at $30^{\circ} \mathrm{C}$ (Scientific 222 oven model, 2003) in sabouraud dextrose agar medium for fungi.

Test assays for antimicrobial activity. The screening of antibacterial activities against Gram + and Gram- bacteria and fungi and the determination of the minimal inhibitory concentration (MIC) were achieved by an adaptation of the agar streak dilution method based on radial diffusion (Hawkey and Lewis, 1994; Sousa et al., 2006). Suspensions of the microorganism were prepared to contain approximately $10^{8} \mathrm{cfu} / \mathrm{mL}$, and the plates containing agar medium were inoculated $(100 \mu \mathrm{L})$. Each sample $(50 \mu \mathrm{L})$ was placed in a hole $(3 \mathrm{~mm}$ depth, $4 \mathrm{~mm}$ diameter) made in the centre of the agar. Under the same conditions, different solutions of ampicillin (antibacterial) and cycloheximide (antifungal) were used as standards. The assays with the standards were carried out using DMSO solutions, which was chosen as the best solvent. After comparative toxicity assays this solvent showed to be not toxic. The MIC was considered to be the lowest concentration of the tested sample able to inhibit the growth of bacteria or fungi, after $24 \mathrm{~h}$. The diameters of the inhibition zones corresponding to the MICs were measured using a ruler, with an accuracy of $0.5 \mathrm{~mm}$. Each inhibition zone diameter was measured three times (three different plates) and the average was considered. A control using only inoculation was also carried out.

\subsection{Antimicrobial activity}

Reagents. BHA (2-tert-butyl-4-methoxyphenol), TBHQ (tert-butylhydroquinone) and $\alpha$-tocopherol were purchased from Sigma (St. Louis, MO, USA). 2,2-Diphenyl-1-picrylhydrazyl (DPPH) was obtained from Alfa Aesar. All other chemicals were obtained from Sigma Chemical Co. (St. Louis, USA). Methanol was obtained from Pronalab (Lisboa, Portugal). Water was treated in a Mili-Q water purification system (TGI Pure Water Systems, USA).

Reducing power assay. The reducing power was determined according to a described procedure (Oyaizu, 1896). Various concentrations of sample extracts $(2.5 \mathrm{~mL})$ were mixed with $2.5 \mathrm{~mL}$ of $200 \mathrm{mmol} / \mathrm{L}$ sodium phosphate buffer ( $\mathrm{pH} 6.6)$ and $2.5 \mathrm{~mL}$ of $1 \%$ potassium ferricyanide. The mixture was incubated at $50^{\circ} \mathrm{C}$ for $20 \mathrm{~min}$. After incubation $2.5 \mathrm{~mL}$ of $10 \%$ triclhoroacetic acid $(\mathrm{w} / \mathrm{v})$ were added and then the mixture was centrifuged at $1000 \mathrm{rpm}$ in a refrigerated centrifuge (Centorion K24OR2003), for $8 \mathrm{~min}$. The upper layer $(5 \mathrm{~mL})$ was mixed with $5 \mathrm{~mL}$ of deionised water and $1 \mathrm{~mL}$ of $0.1 \%$ of ferric chloride, and the absorbance was measured spectrophotometrically at $700 \mathrm{~nm}$. The extract concentration providing 0.5 of absorbance $\left(\mathrm{EC}_{50}\right)$ was calculated from the graph of absorbance registered at $700 \mathrm{~nm}$ against the correspondent extract concentration. BHA and $\alpha$-tocopherol were used as reference compounds.

Scavenging effect assay. The capacity to scavenge the 2,2-diphenyl-1picrylhydrazyl (DPPH) free radical was monitored according to a method reported before (Hatano et al., 1988). Various concentrations of sample extracts $(0.3 \mathrm{~mL})$ were mixed with $2.7 \mathrm{~mL}$ of methanolic solution containing DPPH radicals $\left(6 \times 10^{-5} \mathrm{~mol} / \mathrm{L}\right)$. The mixture was shaken vigorously and left to stand in the dark until stable absorption values were obtained. The reduction of the DPPH radical was measured by monitoring continuously the decrease of absorption at $517 \mathrm{~nm}$. DPPH scavenging effect was calculated as percentage of DPPH discolouration using the equation: \% scavenging effect $=\left[\left(A_{\mathrm{DPPH}}-A_{\mathrm{S}}\right) / A_{\mathrm{DPPH}}\right] \times 100$, where $A_{\mathrm{S}}$ is the absorbance of the solution when the sample extract has been added at a particular level and $A_{\mathrm{DPPH}}$ is the absorbance of the DPPH solution. The extract concentration providing $50 \%$ inhibition $\left(\mathrm{EC}_{50}\right)$ was calculated from the graph of scavenging effect percentage against extract concentration. BHA and $\alpha$-tocopherol were used as reference compounds.

$\beta$-carotene linoleate model system. The antioxidant activity of walnut leaf extracts was evaluated according to a described procedure (Mi-Yae et al., 2003) $\beta$-carotene solution was prepared by dissolving $2 \mathrm{mg}$ of $\beta$ carotene in $10 \mathrm{~mL}$ of chloroform. Two millilitres of this solution were placed in a $100 \mathrm{~mL}$ round-bottom flask. After chloroform removal, at $40{ }^{\circ} \mathrm{C}$ under vacuum, $40 \mathrm{mg}$ of linoleic acid, $400 \mathrm{mg}$ of Tween 80 emulsifier, and $100 \mathrm{~mL}$ of distilled water were added to the flask under vigorous shaking. Aliquots $(4.8 \mathrm{~mL})$ of this emulsion were transferred into different test tubes containing $0.2 \mathrm{~mL}$ of different concentrations of walnut leaf extracts. The tubes were shaken and incubated at $50{ }^{\circ} \mathrm{C}$ in a water bath. As soon as the emulsion was added to each tube, the zero time absorbance at $470 \mathrm{~nm}$ was measured. Absorbance readings were then recorded until the control sample had changed colour. A blank assay, devoid of $\beta$-carotene, was prepared for background subtraction. Antioxidant activity was calculated using the following equation: Antioxidant activity $=(\beta$-carotene content after $2 \mathrm{~h}$ of assay/initial $\beta$-carotene content $) \times 100$. The assays were carried out in triplicate and the results were expressed as mean values \pm standard deviations. The extract concentration providing $50 \%$ antioxidant activity $\left(\mathrm{EC}_{50}\right)$ was calculated from the graph of antioxidant percentage against extract concentration. TBHQ was used as reference compound.

\section{Results and discussion}

\subsection{Phenolic compounds analysis}

The HPLC-DAD analysis of walnut leaves aqueous extracts revealed the presence of several hydroxycinnamic acid and flavonoid derivatives. By this means, in the six analysed cultivars, it was possible to identify ten phenolic compounds: 3- and 5-caffeoylquinic acids, 3- and 4- $p$-coumaroylquinic acids, $p$-coumaric acid, quercetin 3-galactoside, quercetin 3-pentoside derivative, quercetin 3-arabinoside, quercetin 3-xyloside and quercetin 3-rhamnoside (Figs. 1 and 2). 5-Caffeoylquinic and $p$-coumaric acids were not described before (Amaral et al., 2004) in these cultivars, being detected now.

Juglone was not found in the samples, which is not surprising considering its slight solubility in hot water and that it is volatile by steam (Anonimous, 1989).

The quantification of the phenolics present in the different cultivars extracts revealed a high amount of these compounds, ranging from ca. 65 to $73 \mathrm{~g} / \mathrm{kg}$, dry basis. Flavonols were always the major compounds, varying between $54.8 \%$ and $62.9 \%$ of total phenolics (Table 1). Mayette and Franquette cultivars showed the highest content of compounds, while Lara presented the lowest one (Table 1).

All samples exhibited the same phenolic profile, in which quercetin 3-galactoside was the major compound, corresponding to ca. $26.8 \%$ of total phenolics, followed by 3-caffeoylquinic acid (ca. 19.7\% of total compounds) (Fig. 3). $p$-Coumaric acid was the minor compound, representing ca. $1.4 \%$ of total phenolics (Fig. 3).

In a previous work of our research group (Amaral et al., 2004) we study the evolution of phenolic compounds in the leaves of different walnut varieties from May to September. In that study no significant variation were observed according the sampling time. However, in the paper herein we have used the samples collected in May, the collection time with the highest quantity of phenolic compounds. When comparing the results with those previously obtained (Amaral et al., 2004) it could be noticed that the total phenolics content found now is considerably higher, mainly due to an increase phenolic acids derivatives contents. Considering that the analysed leaves were collected in the same period and from the same trees of the previous work, this 
<smiles>[2H]c1cc(/C=C/C(=O)OC2CC(O)(C(=O)O)CC(O)C2O)ccc1O</smiles>

$\mathbf{R}$

$1 \mathrm{OH}$

$2 \mathrm{H}$<smiles>O=C(/C=C/c1ccc(O)c(O)c1)OC1CC(O)(C(=O)O)CC(O)C1O</smiles>

3<smiles>O=C(/C=C/c1ccc(O)cc1)OC1C(O)CC(O)(C(=O)O)CC1O</smiles>

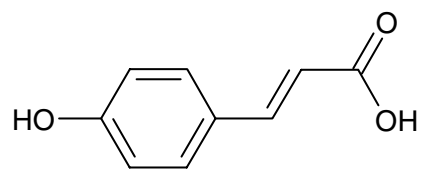

5<smiles>O=c1c(O)c(-c2ccc(O)c(O)c2)oc2cc(O)cc(O)c12</smiles>

galactose

pentose

arabinose

xylose

10 rhamnose

Fig. 1. Chemical structures of the phenolic compounds identified in walnut leaves. (1) 3-caffeoylquinic acid; (2) 3-p-coumaroylquinic acid; (3) 5-caffeoylquinic acid; (4) 4-p-coumaroylquinic acid; (5) p-coumaric acid; (6) quercetin 3-galactoside; (7) quercetin 3-pentoside derivative; (8) quercetin 3-arabinoside; (9) quercetin 3-xyloside; (10) quercetin 3-rhamnoside.

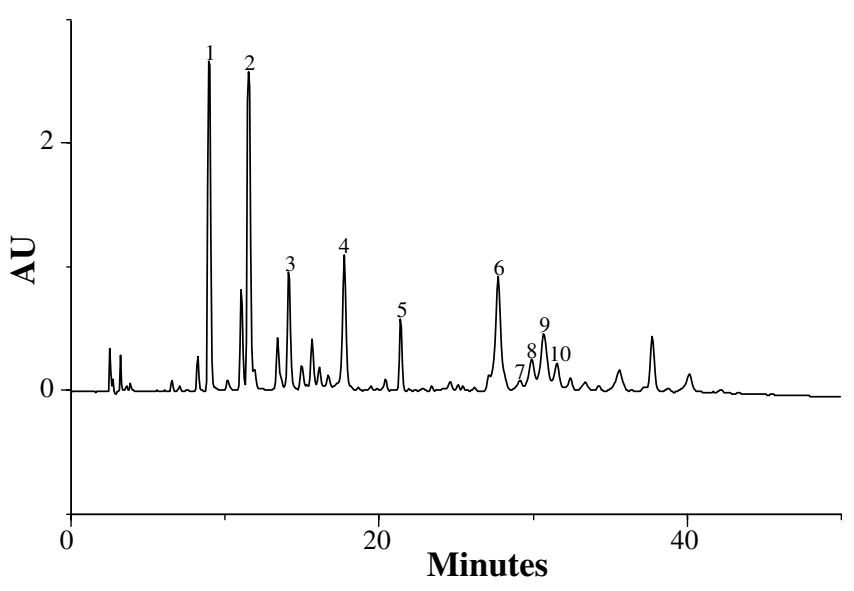

Fig. 2. HPLC-DAD of phenolic compounds in walnut leaves $(C v$. Mayette). Detection at $320 \mathrm{~nm}$. Peaks: (1) 3-caffeoylquinic acid; (2) 3-p-coumaroylquinic acid; (3) 5-caffeoylquinic acid; (4) 4-p-coumaroylquinic acid; (5) $p$-coumaric acid; (6) quercetin 3-galactoside; (7) quercetin 3-pentoside derivative; (8) quercetin 3-arabinoside; (9) quercetin 3xyloside; (10) quercetin 3-rhamnoside.

rise could be attributed to the drying procedure to which they were subjected: in this work the leaves were freeze- dried, which is a faster and less drastic drying process than that of ventilated stove at $30^{\circ} \mathrm{C}$ for five days used before (Amaral et al., 2004), that allows enzymatic reactions, with possible alteration and loss of compounds.

Nevertheless, the influence of environmental factors cannot be excluded. As observed before, quercetin 3-galactoside is the main compound, but a decrease in its relative amount was now observed (24.3-30.4\%). In addition, $p$-coumaric acid, not identified before, is now the minor compound, as above mentioned.

\subsection{Antimicrobial activity}

The walnut leaves aqueous extracts were screened for their antimicrobial properties against $B$. cereus, B. subtilis, $S$. aureus, E. coli, $P$. aeruginosa, $K$. pneumoniae, C. albicans and $C$. neoformans. The minimal inhibitory concentration (MIC) values for the tested bacteria and fungi (Table 2) were determined as an evaluation of the antimicrobial activity of the samples.

Despite all the cultivars revealed antimicrobial activity, the response for each microorganism tested was different. The extracts presented similar antimicrobial capacity, 


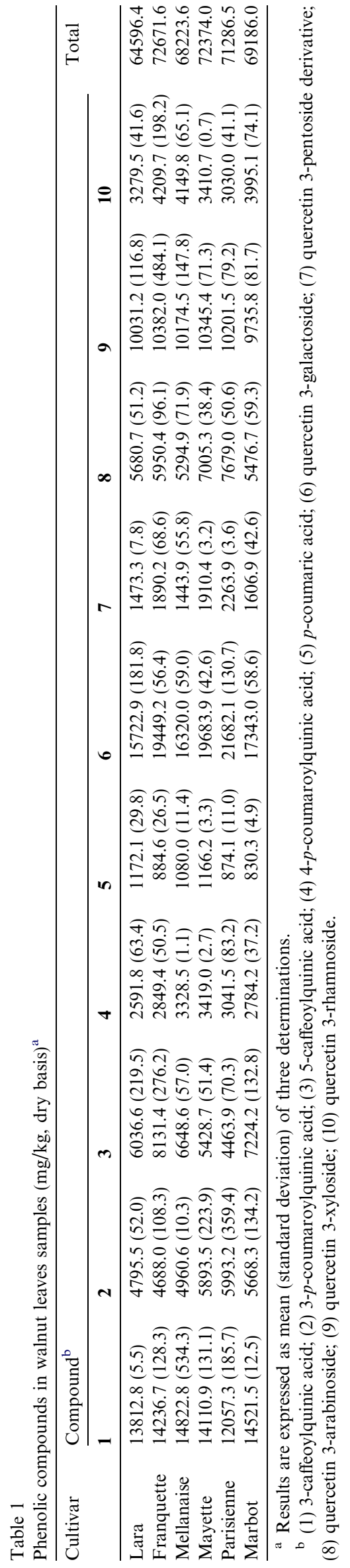

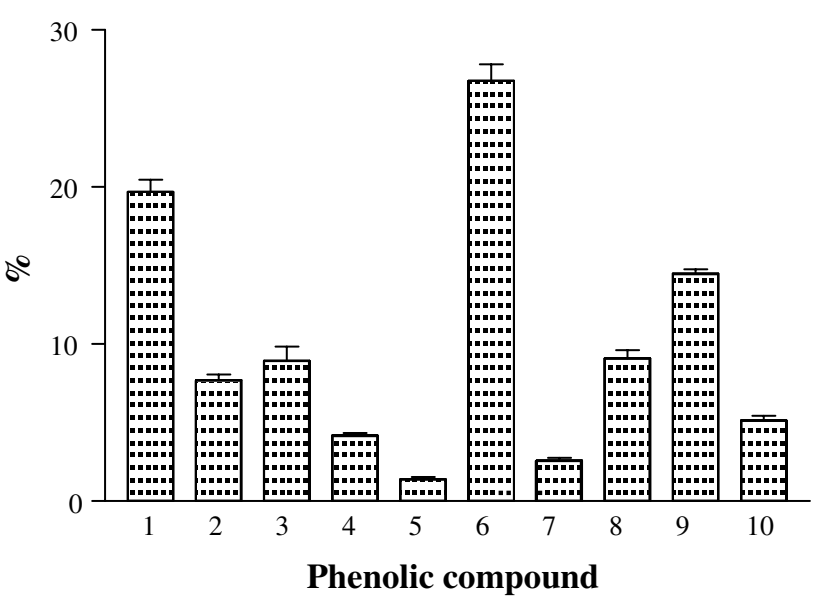

Fig. 3. Phenolic profile of walnut leaves. Values represent mean, and standard error bars are on the top of each column. Compounds: (1) 3-caffeoylquinic acid; (2) 3-p-coumaroylquinic acid; (3) 5-caffeoylquinic acid; (4) 4-p-coumaroylquinic acid; (5) p-coumaric acid; (6) quercetin 3-galactoside; (7) quercetin 3-pentoside derivative; (8) quercetin 3-arabinoside; (9) quercetin 3-xyloside; (10) quercetin 3-rhamnoside.

inhibiting only Gram + bacteria and in the order B. cereus $>S$. aureus $>>B$. subtilis. B. cereus was the most susceptible microorganism, presenting MICs of $0.1 \mathrm{mg} / \mathrm{mL}$. The tested Gram- bacteria (E. coli, P. aeruginosa and K. peumoniae) and fungi (C. albicans and C. neoformans) species were resistant to all cultivars. The selectivity obtained for this walnut leaves is clearly different from that of walnut bark, which revealed a broad spectrum antimicrobial activity: the bark inhibited the growth of several species of pathogenic microorganisms, representing both Gram+ (S. aureus and S. mutatis) and Gram- (E. coli and P. aeruginosa) bacteria and a pathogenic yeast ( $C$. albicans) (Alkhawajah, 1997). Recently, Darmani et al. (2006) reported the growth inhibition of various cariogenic bacteria (Streptococcus mutans, Streptococcus salivarius, Lactobacillus casei and Actinomyces viscosus) by walnut aqueous extracts. The most sensitive organisms were $A$. viscosus, followed by $S$. mutans, $S$. salivarius, with $L$. casei being the most resistant. All these species are Gram + bacteria, which is consistent with our results.

Lara walnut leaves proved to be the most promissory cultivar to inhibit Gram+ bacteria growth, presenting lower MICs and higher growth inhibition zones. Attending to this fact, this sample was submitted to further antibacterial assays, against 18 Staphylococcus sp. strains clinically isolated from sputum, pus and blood (Table 3 ). The results obtained suggest a broad activity of Lara walnut leaves against all the $S$. aureus strains, in a concentration-dependent manner. The strains isolated from sputum seem to be the most susceptible: they exhibited MICs of $0.1 \mathrm{mg} /$ $\mathrm{mL}$, while for the strains isolated from pus and blood it ranged between 0.1 and $1 \mathrm{mg} / \mathrm{mL}$. S. bovines, S. slimi, $S$. sintata and $S$. capitis strains were also more resistant, with MICs of $1 \mathrm{mg} / \mathrm{mL}$. S. chromogenes was the less susceptible Staphylococcus species, being the strain isolated 
Table 2

Antimicrobial activity of leaf extract of different walnut cultivars

\begin{tabular}{|c|c|c|c|c|c|c|c|c|}
\hline \multirow[t]{2}{*}{ Cultivar } & \multicolumn{8}{|l|}{ MIC (mg/mL) } \\
\hline & B. cereus & B. subtilis & S. aureus & P. aeruginosa & E. coli & K. peumoniae & C. albicans & C. neoformans \\
\hline Lara & $0.1(++++)$ & $10(++++)$ & $0.1(++++)$ & $100(-)$ & $100(-)$ & $100(-)$ & $100(-)$ & $100(-)$ \\
\hline Franquette & $0.1(++)$ & $10(+++)$ & $0.1(++)$ & $100(-)$ & $100(-)$ & $100(-)$ & $100(-)$ & $100(-)$ \\
\hline Mellanaise & $0.1(++)$ & $10(+++)$ & $0.1(++)$ & $100(-)$ & $100(-)$ & $100(-)$ & $100(-)$ & $100(-)$ \\
\hline Mayette & $0.1(++)$ & $10(++++)$ & $1(++++)$ & $100(-)$ & $100(-)$ & $100(-)$ & $100(-)$ & $100(-)$ \\
\hline Parisienne & $0.1(++)$ & $10(++)$ & $1(++++)$ & $100(-)$ & $100(-)$ & $100(-)$ & $100(-)$ & $100(-)$ \\
\hline Marbot & $0.1(++++)$ & $10(++)$ & $1(++++)$ & $100(-)$ & $100(-)$ & $100(-)$ & $100(-)$ & $100(-)$ \\
\hline
\end{tabular}

No antimicrobial activity $(-)$, inhibition zone $<1 \mathrm{~mm}$. Slight antimicrobial activity $(+)$, inhibition zone $2-3 \mathrm{~mm}$. Moderate antimicrobial activity $(++)$, inhibition zone 4-5 mm. High antimicrobial activity $(+++)$, inhibition zone $6-9 \mathrm{~mm}$. Strong antimicrobial activity $(++++)$, inhibition zone $>9$ mm. Standard deviation $\pm 0.5 \mathrm{~mm}$.

Table 3

Antimicrobial activities (inhibition zones in $\mathrm{mm}$ ) of different $C v$. Lara leaf extract concentration on clinical isolates of Staphylococcus sp. strains

\begin{tabular}{|c|c|c|c|c|}
\hline \multirow[t]{2}{*}{ Strain } & \multirow[t]{2}{*}{ Biological fluid } & \multicolumn{3}{|c|}{$C v$ Lara leaf extract $(\mathrm{mg} / \mathrm{mL})$} \\
\hline & & 0.1 & 1 & 10 \\
\hline S. aureus ESA 11 & Sputum & $10.5 \pm 1.29$ & $10.3 \pm 0.50$ & $12.5 \pm 1.29$ \\
\hline S. aureus ESA 12 & Sputum & $8.8 \pm 0.50$ & $13.5 \pm 1.29$ & $17.0 \pm 0.82$ \\
\hline S. aureus ESA 13 & Sputum & $12.3 \pm 0.96$ & $16.5 \pm 2.65$ & $19.3 \pm 1.71$ \\
\hline S. aureus ESA 14 & Sputum & $10.8 \pm 0.96$ & $13.3 \pm 0.50$ & $19.0 \pm 0.82$ \\
\hline S. aureus ESA 16 & Sputum & $6.5 \pm 7.51$ & $12.5 \pm 1.00$ & $15.0 \pm 0.82$ \\
\hline S. aureus ESA 21 & Sputum & $12.5 \pm 2.08$ & $18.8 \pm 1.89$ & $19.8 \pm 5.32$ \\
\hline S. aureus ESA 10 & Pus & $0.0 \pm 0.00$ & $12.3 \pm 2.63$ & $29.0 \pm 6.73$ \\
\hline S. aureus ESA 15 & Pus & $10.5 \pm 2.38$ & $11.5 \pm 1.00$ & $13.3 \pm 2.36$ \\
\hline S. aureus ESA 20 & Pus & $6.0 \pm 6.93$ & $11.5 \pm 1.73$ & $17.0 \pm 1.63$ \\
\hline S. aureus ESA 17 & Blood & $11.5 \pm 9.40$ & $15.8 \pm 2.5$ & $18.3 \pm 2.06$ \\
\hline S. aureus ESA 18 & Blood & $0.0 \pm 0.00$ & $15.8 \pm 1.71$ & $18.8 \pm 2.06$ \\
\hline S. aureus ESA 19 & Blood & $13.3 \pm 2.06$ & $17.5 \pm 5.07$ & $17.3 \pm 2.87$ \\
\hline S. capitis ESA 23 & Sputum & $0.0 \pm 0.00$ & $9.8 \pm 1.50$ & $10.3 \pm 1.26$ \\
\hline S. sintata ESA 24 & Sputum & $0.0 \pm 0.00$ & $0.0 \pm 0.00$ & $11.3 \pm 1.50$ \\
\hline S. slimi ESA 26 & Sputum & $0.0 \pm 0.00$ & $16.5 \pm 1.91$ & $16.0 \pm 2.16$ \\
\hline S. bovines ESA 27 & Pus & $0.0 \pm 0.00$ & $11.3 \pm 2.63$ & $15.3 \pm 0.50$ \\
\hline S. chromogenes ESA 25 & Pus & $0.0 \pm 0.00$ & $0.0 \pm 0.00$ & $14.0 \pm 1.63$ \\
\hline S. chromogenes ESA 28 & Blood & $0.0 \pm 0.00$ & $0.0 \pm 0.00$ & $0.0 \pm 0.00$ \\
\hline
\end{tabular}

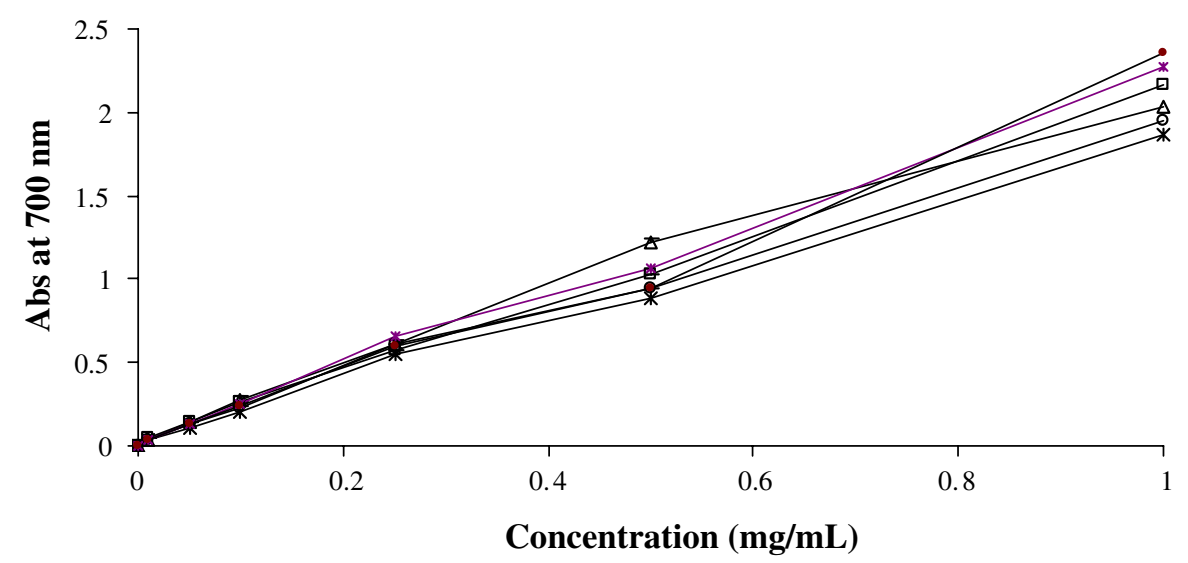

$\rightarrow$ Mayette $\rightarrow$ Mellanaise $\triangle$ Parisienne $\rightarrow$ Marbot $\rightarrow$ Lara $\rightarrow$ Franquette

Fig. 4. Reducing power values of different cultivars of walnut leaf extracts. Each value is expressed as mean \pm standard deviation.

from blood the most resistant one. These results are important considering that $S$. aureus can produce several types of enterotoxins that cause gastroenteritis, which is a major food-borne disease in most countries (Halpin-Dohnalek and Marth, 1989). Natural products have been a particularly rich source of anti-infective agents. Flavonoids 
showed posses antimicrobial activity, and quercetin and other related compounds acts essentially by enzyme inhibition of DNA gyrase (Cushnie and Lamb, 2005).

\subsection{Antioxidant activity}

In the reducing power assay, the yellow colour of the test solution changes to various shades of green and blue, depending on the reducing power of each extract. The presence of reducers (i.e. antioxidants) causes the reduction of the $\mathrm{Fe}^{3+} /$ ferricyanide complex to the ferrous form. Therefore, $\mathrm{Fe}^{2+}$ concentration can be monitorized by measuring the formation of Perl's Prussian blue at $700 \mathrm{~nm}$. The reducing power of the walnut leaves extracts increased in a concentration-dependent way, as shown in Fig. 4. Walnut leaves showed high reducing powers at very low concentrations $(<1 \mathrm{mg} / \mathrm{mL})$, being even more potent than BHA $\left(A_{700}=0.12\right.$ at $\left.3.6 \mathrm{mg} / \mathrm{mL}\right)$ and $\alpha$-tocopherol $\left(A_{700}=0.13\right.$ at $8.6 \mathrm{mg} / \mathrm{mL}$ ) standards. The reducing power of the different cultivars was very similar and followed the order Lara $>$ Parsienne $\sim$ Mellanaise $\sim$ Franquette $>$ Mayette $>$ Marbot (Table 4).

The radical scavenging activity assay constitutes a screening method currently used to provide basic information on the antiradical activity of extracts. The walnut leaves extracts displayed an effective concentration-depen-

Table 4

$\mathrm{EC}_{50}$ values $(\mathrm{mg} / \mathrm{mL})$ of different walnut leaf samples

\begin{tabular}{llll}
\hline Cultivar & $\begin{array}{l}\text { Reducing power } \\
\left(\mathrm{EC}_{50}\right)\end{array}$ & $\begin{array}{l}\mathrm{DPPH} \\
\left(\mathrm{EC}_{50}\right)\end{array}$ & $\begin{array}{l}\beta \text {-carotene bleaching } \\
\left(\mathrm{EC}_{50}\right)\end{array}$ \\
\hline Lara & 0.192 & 0.151 & 0.742 \\
Franquette & 0.208 & 0.156 & 0.894 \\
Mellanaise & 0.206 & 0.195 & 1.645 \\
Mayette & 0.215 & 0.187 & 0.444 \\
Parisienne & 0.201 & 0.170 & 0.764 \\
Marbot & 0.229 & 0.202 & 0.819 \\
\hline
\end{tabular}

dent scavenging capacity, for concentrations below $0.5 \mathrm{mg} / \mathrm{mL}$ (Fig. 5). Lara and Marbot cultivars showed the highest and the lowest activities, respectively (Table 4). These results are much better than those obtained for BHA $(96.0 \%$ at $3.6 \mathrm{mg} / \mathrm{mL})$ and $\alpha$-tocopherol $(95.0 \%$ at $8.6 \mathrm{mg} / \mathrm{mL})$.

The antioxidant activity of walnut leaves extracts measured by the bleaching of $\beta$-carotene is shown in Fig. 6. In the tested system linoleic acid free radical attacks the highly unsaturated $\beta$-carotene. The presence of different antioxidants can hinder the extent of $\beta$-carotene-bleaching by neutralizing the linoleate-free radical and other free radicals formed in the system (Denyer and Stewart, 1998). In the absence of antioxidants the absorbance at $470 \mathrm{~nm}$ decreases rapidly, whereas in their presence, the colour, and thus absorbance, is retained for a longer time. The results obtained with walnut leaf extracts indicated a concentration-dependent antioxidant capacity (Fig. 6), following the order Mayette $>$ Lara $>$ Parisienne $>$ Marbot $>$ Franquette $>$ Mellanaise (Table 4). However, the protection of $\beta$-carotene bleaching provided by the samples was lower than that TBHQ standard $(82.2 \%$ at $2 \mathrm{mg} / \mathrm{mL})$.

The antioxidant capacity of walnut polyphenols has already been described. Anderson et al. (2001) reported the in vitro inhibition of human plasma and low density lipoproteins (LDL) oxidation by a walnut extract containing ellagic acid, gallic acid and flavonoids.

Fukuda et al. (2003) described the remarkable superoxide dismutase-like activity and radical scavenging effect of 14 walnut polyphenols and recently examined the in vivo antioxidative effect of a polyphenol-rich walnut extract on oxidative stress in mice with type 2 diabetes (Fukuda et al., 2004). In walnut leaves we have found a considerable amount of quercetin heterosides. Quercetin as other flavonoids are able to protect against chemically induced DNA damage in human lymphocytes and increase the total antioxidant capacity of plasma (Wilms et al.,

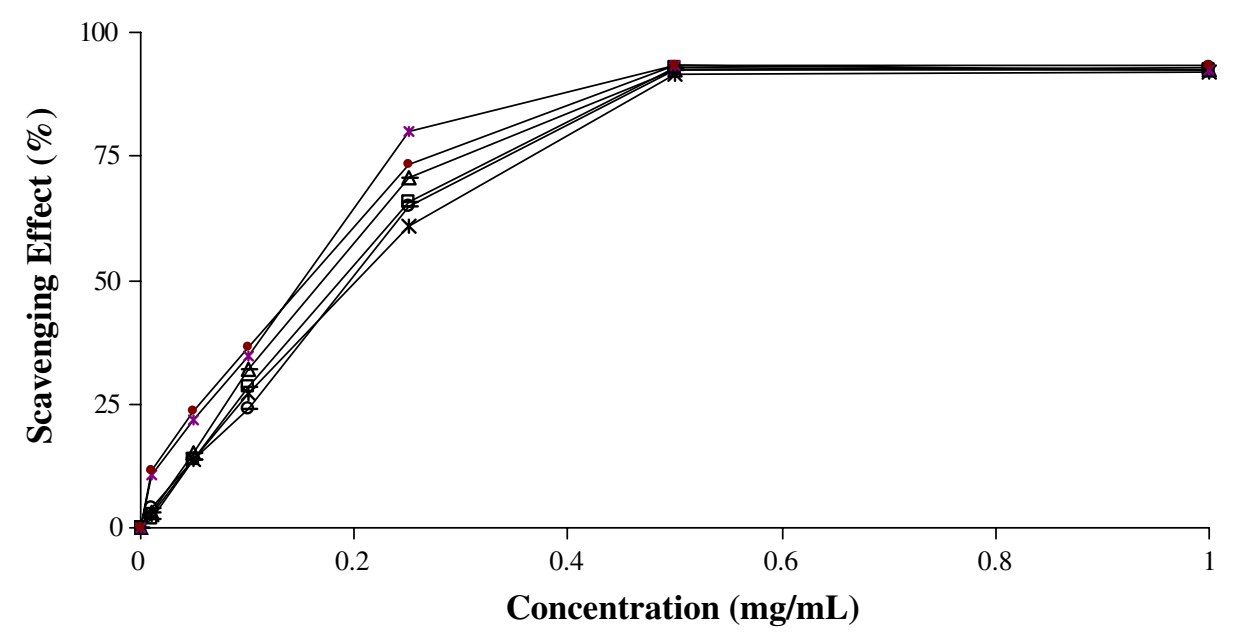

$\multimap$ Mayette $\rightarrow$ Mellanaise $\triangle$ Parisienne $\rightarrow$ Marbot $\rightarrow$ Lara $\rightarrow$ Franquette

Fig. 5. Scavenging effect on DPPH of different cultivars of walnut leaf extracts. Each value is expressed as mean \pm standard deviation. 


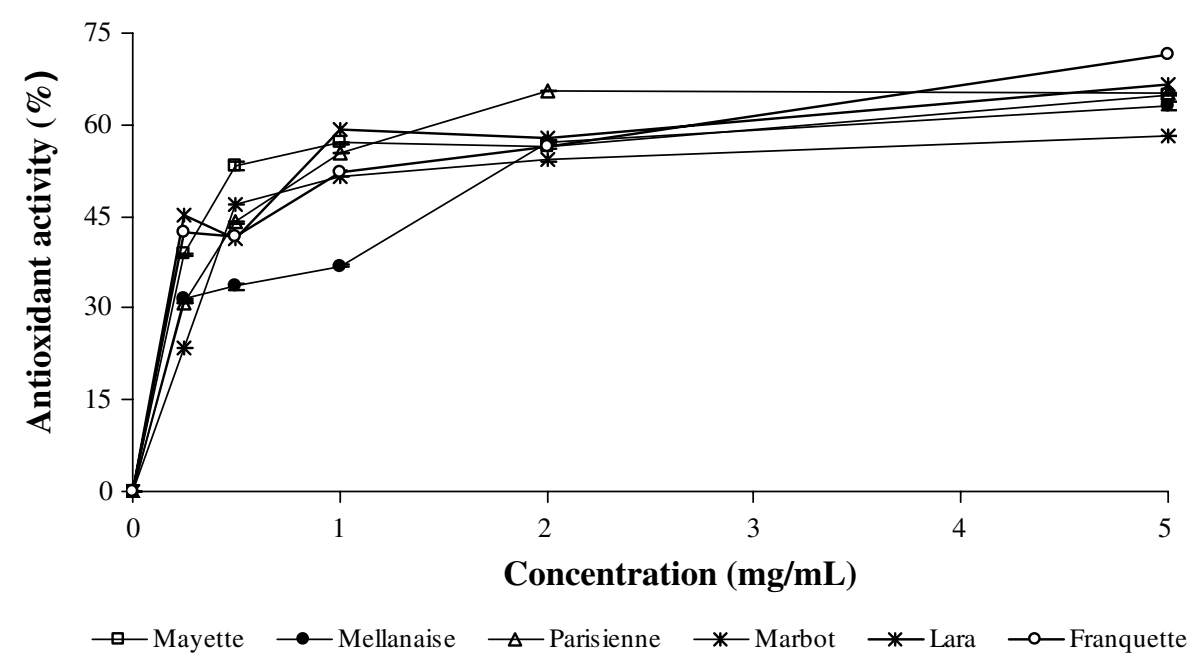

Fig. 6. Antioxidant activity ( $\%$ ) by $\beta$-carotene bleaching method of different cultivars of walnut leaf extracts. Each value is expressed as mean \pm standard deviation.

2005; Tieppo et al., 2007), increased genomic stability in cirrhotic rats, suggesting beneficial effects, probably by its antioxidant properties. Flavonoids can also protect cells by acting as free radical scavengers, inhibiting DNA damage and mutagenicity (Edenharder and Grünhage, 2003; Salter et al., 2004). Otherwise, the hydroxycinnamic acid derivatives, such as 5-caffeoylquinic acid and caffeic acid present an antioxidant activity upon low density lipoprotein peroxidation (Laranjinha et al., 1994). So, a synergistic effect between quercetin heterosides and hydroxycinnamic derivatives can explain the walnut leaves extract antioxidant activity (Liu, 2003). Despite these studies, this is the first time that the antioxidant potential of walnut leaves is reported.

In conclusion, the results obtained in this study demonstrate that walnut leaves may be a good candidate for employment as antimicrobial agent against bacteria responsible for human gastrointestinal and respiratory tract infections. These results are particularly important against $S$. aureus, due to its ability to produce enterotoxins and exceptionally resistance to a number of phytochemicals. Walnut leaves may also constitute a good source of healthy compounds, namely phenolics, suggesting that it could be useful in the prevention of diseases in which free radicals are implicated. Despite some studies performed with walnut fruits, as far as we know, this is the first report considering the antioxidant and antimicrobial potential of walnut leaves.

\section{Acknowledgements}

The authors are grateful to INTERREG III A Program, Project PIREFI for financial support of this work.

\section{References}

Alkhawajah, A.M., 1997. Studies on the antimicrobial activity of Juglans regia. American Journal of Chinese Medicine 25, 175-180.
Amaral, J.S., Seabra, R.M., Andrade, P.B., Valentão, P., Pereira, J.A., Ferreres, F., 2004. Phenolic profile in the quality control of walnut (Juglans regia L.) leaves. Food Chemistry 88, 373-379.

Anderson, K.J., Teuber, S.S., Gobeille, A., Cremin, P., Waterhouse, A.L., Steinberg, F.M., 2001. Walnut polyphenolics inhibit in vitro human plasma and LDL oxidation. The Journal of Nutrition 131, 2837-2842.

Anonimous, 1989. In: Budavari, S. (Ed.), The Merck Index, 11th ed. Merck \& Co., Inc., New Jersey, USA, p. 829.

Anonimous, 1999. Recenseamento Geral Agrícola. Instituto Nacional de Estatística, Portugal.

Bruneton, J., 1993. Pharmacogosie, phytochimie, plantes médicinales. Tec.\& Doc.- Lavoisier, Paris, p. 348.

Clark, A.M., Jurgens, T.M., Hufford, C.D., 1990. Antimicrobial activity of juglone. Phytotherapy Research 4, 11-14.

Cushnie, T.P.T., Lamb, A.J., 2005. Antimicrobial activity of flavonoids. International Journal of Antimicrobial Agents 26, 343-356.

Darmani, H., Nusayr, T., Al-Hiyasat, A.S., 2006. Effects of extracts of miswak and derum on proliferation of Balb/C 3T3 fibroblasts and viability of cariogenic bacteria. International Journal of Dental Hygiene 4, 62-66.

Denyer, S.P., Stewart, G.S.A.B., 1998. Mechanisms of action of disinfectants. International Biodeterioration and Biodegradation 41, 261-268.

Edenharder, R., Grünhage, D., 2003. Free radical scavenging abilities of flavonoids as mechanism of protection against mutagenicity induced by tert-butyl hydroperoxide or cumene hydroperoxide in Salmonella typhimurium TA102. Mutation Research 540, 1-18.

Fukuda, T., Ito, H., Yoshida, T., 2003. Antioxidative polyphenols from walnuts (Juglans regia L.). Phytochemistry 63, 795-801.

Fukuda, T., Ito, H., Yoshida, T., 2004. Effect of the walnut polyphenol fraction on oxidative stress in type 2 diabetes mice. BioFactors 21, 251-253.

Gîrzu, M., Carnat, A., Privat, A.-M., Fiaplip, J., Carnat, A.-P., Lamaison, J.-L., 1998. Sedative effect of walnut leaf extract and juglone, an isolated constituent. Pharmaceutical Biology 36, 280-286.

Halpin-Dohnalek, M.I., Marth, E.H., 1989. Growth and production of enterotoxin A by Staphylococcus aureus in cream. Journal of Dairy Science 72, 2266-2275.

Hatano, T., Kagawa, H., Yasuhara, T., Okuda, T., 1988. Two new flavonoids and other constituents in licorice root: their relative astringency and scavenging effects. Chemical \& Pharmaceutical Bulletin 36, 2090-2097.

Hawkey, P.M., Lewis, D.A., 1994. Medical Bacterology - A Practical Approach. Oxford University, UK, pp. 181-194.

Laranjinha, J.A., Almeida, L.M., Madeira, V.M., 1994. Reactivity of dietary phenolic acids with peroxyl radicals: antioxidant activity upon 
low density lipoprotein peroxidation. Biochemical Pharmacology 48, 487-494.

Liu, R.H., 2003. Health benefits of fruits and vegetables are from additive and synergistic combination of phytochemicals. American Journal of Clinical Nutrition 78, 517S-520S, 9.

Middleton Jr., E., 1998. Effect of plant flavonoids on immune and inflammatory cell function. Advances in Experimental Medicine and Biology 439, 175-182.

Mi-Yae, S., Tae-Hun, K., Nak-Ju, S., 2003. Antioxidants and free radical scavenging activity of Phellinus baumii (Phellinus of Hymenochaetaceae) extracts. Food Chemistry 82, 593-597.

Oyaizu, M., 1896. Studies on products of browning reactions: antioxidative activities of products of browning reaction prepared from glucosamine. Japanese Journal of Nutrition 44, 307-315.

Pulido, R., Bravo, L., Saura-Calixto, F., 2000. Antioxidant activity of dietary polyphenols as determined by a modified ferric reducing/ antioxidant power assay. Journal of Agricultural and Food Chemistry 48, 3396-3402.

Qa'dan, F., Thewaini, A.-J., Ali, D.A., Afifi, R., Elkhawad, A., Matalka, K.Z., 2005. The antimicrobial activities of Psidium guajava and Juglans regia leaf extracts to acne-developing organisms. American Journal of Chinese Medicine 33, 197-204.

Salter, L., Clifford, T., Morley, N., Gould, D., Campbell, S., Curnow, A., 2004. The use of comet assay data with a simple reaction mechanism to evaluate the relative effectiveness of free radical scavenging by quercetin, epigallocatechin gallate, and $N$-acetylcysteine in UV-irradiated MRC5 lung fibroblasts. Journal of Photochemistry and Photobiology B: Biology 75, 57-61.

Silva, B.M., Andrade, P.B., Valentão, P., Ferreres, F., Seabra, R.M., Ferreira, M.A., 2004. Quince (Cydonia oblonga Miller) fruit (pulp, peel, and seed) and jam: antioxidant activity. Journal of Agricultural and Food Chemistry 52, 4705-4712.

Solar, A., Colaric, M., Usenik, V., Stampar, F., 2006. Seasonal variation of selected flavonoids, phenolic acids and quinones in annual shorts of common walnut (Juglans regia L.). Plant Science 170, 461-543.

Sousa, A., Ferreira, I.C.F.R., Calhelha, R., Andrade, P., Valentão, P., Seabra, R., Estevinho, L., Bento, A., Pereira, J.A., 2006. Phenolics and antimicrobial activity of traditional stoned table olives "Alcaparras". Bioorganic \& Medicinal Chemistry 14, 8533-8538.

Stampar, F., Solar, A., Hudina, M., Veberic, R., Colaric, M., 2006. Traditional walnut liqueur - cocktail of phenolics. Food Chemistry 95, 627-631.

Tieppo, J., Vercelino, R., Dias, A.S., Silva Vaz, M.F., Silveira, T.R., Marroni, C.A., Marroni, N.P., Henriques, J.A.P., Picada, J.N., 2007. Evaluation of the protective effects of quercetin in the hepatopulmonary syndrome. Food and Chemical Toxicology 45, 1140-1146.

Tseng, T.-H., Kao, E.-S., Chu, C.-Y., Chou, F.-P., Lin Wu, H.-W., Wang, C.-J., 1997. Protective effects of dried flower extracts of Hibiscus sabdariffa L. against oxidative stress in rat primary hepatocytes. Food and Chemical Toxicology 35, 1159-1164.

Valnet, J., 1992. Phytothérapie Traitement des maladies par les plantes. Maloine, Paris, pp. 476-478.

Van Hellemont, J., 1986. Compendium de phytotherapie. Association Pharmaceutique Belge, Bruxelles, pp. 214-216.

Wichtl, M., Anton, R., 1999. Plantes thérapeutiques. Tec.\& Doc., Paris, pp. 291-293.

Wilms, L.C., Hollman, P.C., Boots, A.W., Kleinjans, J.C., 2005. Protection by quercetin and quercetin-rich fruit juice against induction of oxidative DNA damage and formation of BPDE-DNA adducts in human lymphocytes. Mutation Research 582, 155-162. 